\title{
Effects of storm events on the shelf-to-basin sediment transport in the southwestern end of the Gulf of Lions (Northwestern Mediterranean)
}

\author{
A. Palanques ${ }^{1}$, P. Puig ${ }^{1}$, J. Guillén ${ }^{1}$, X. Durrieu de Madron ${ }^{2}$, M. Latasa ${ }^{3}$, R. Scharek ${ }^{3}$, and J. Martin ${ }^{1}$ \\ ${ }^{1}$ Institut de Ciències del Mar (CSIC), Passeig Maritim de la Barceloneta, 37-49, Barcelona 08003, Spain \\ ${ }^{2}$ CEFREM, CNRS, UMR 5110, University of Perpignan, 52 Avenue Paul Alduy, 66860 Perpignan Cedex, France \\ ${ }^{3}$ Centro Oceanográfico de Gijón (IEO), Av. Príncipe de Asturias 70 bis, 33212 Xixón - Gijón, Spain
}

Received: 19 June 2010 - Revised: 28 December 2010 - Accepted: 8 January 2011 - Published: 15 March 2011

\begin{abstract}
Shelf-to-basin sediment transport during storms was studied at the southwestern end of the Gulf of Lions from November 2003 to March 2004. Waves, near-bottom currents, temperature and sediment fluxes were measured on the inner shelf at 28-m depth, in the Cap de Creus submarine canyon head at 300-m depth and in the northwestern Mediterranean basin at 2350-m depth. This paper is a synthesis of results published separately in different papers; it includes some new data and focusses on the subject of storms. It is the first paper in which simultaneous data about the effect of storms on the shelf, the slope and in the basin are shown together. During the winter studied, there were two severe E-SE storms with significant wave heights $\geq 7 \mathrm{~m}$ : one in December 2003 and one in February 2004. During these storms, coastal water was exported off-shelf producing strong near-bottom currents (up to $82 \mathrm{~cm} \mathrm{~s}^{-1}$ ) at the canyon head that resuspended sediment and increased the downcanyon sediment fluxes by several orders of magnitude. The suspended sediment flux increase in the canyon head was much larger during the February storm than during the December storm. At the deep basin site, particle fluxes also increased drastically (1-2 orders of magnitude) immediately after the February storm but not after the December storm. The reason was that the February storm was reinforced by dense shelf water cascading and was long enough $(43 \mathrm{~h})$ to transfer large amounts of resuspended sediment from shallow shelf areas to the canyon head and from there to the northwestern Mediterranean basin. Thus, in the western Gulf
\end{abstract}

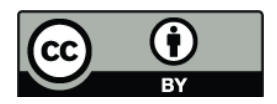

Correspondence to: A. Palanques (albertp@icm.csic.es) of Lions, severe winter E-SE storms occurring during the dense shelf water cascading period can significantly increase the transfer to deep-sea $(>2000 \mathrm{~m})$ environments of shelf and slope resuspended material, including anthropogenic contaminants and organic matter.

\section{Introduction}

The effects of strong storm events in the Mediterranean are relatively well known in the coastal zone where they affect the coastal morphology and can damage many infrastructures, which have been created as a consequence of high anthropogenic pressure. However, the offshore effects of these events are less well known. At sea, storm-waves generate bed shear stresses sufficient to resuspend shelf and even upper slope sediments, increasing water turbidity and sediment transport (Palanques et al., 2002; Puig et al., 2003). Storm events redistribute not only bottom sediment but also all the associated matter as well, such as organic matter and pollutants. The final fate of these substances during storm events is not always well known but it may have an impact in the marine ecosystems. A conceptual model can be summarized from previous studies. The sediment supplied from rivers is trapped on the inner shelf (Geyer et al., 2000; Crockett and Nittrouer, 2004). This sediment is resuspended during moderate storms, transported offshore and deposited on the middle shelf (Traykovski et al., 2000). Finally, the most energetic storms can resuspend this sediment making it available for transport towards the outer shelf and upper slope (Ogston et al., 2000; Puig et al., 2003; Fan et al., 2004). However, the processes and their role in this model

Published by Copernicus Publications on behalf of the European Geosciences Union. 
are very complex and remain poorly understood. In addition, field data are scarce and local, leaving many areas uncovered, and the transfer towards deep environments has been studied little. Storms have been invoked as a plausible triggering mechanism of major events of downcanyon transport in present times (Van Weering et al., 2002; Oliveira et al., 2007; De Stigter et al., 2007), although direct observations of this connection are still pending. Most of the existing studies are based on coastal or slope observations but simultaneous coastal, slope and deep basin data are very scarce.

Many of the results presented herein have been published in a variety of papers (i.e. Guillén et al., 2006; Palanques et al., 2006, 2009) dealing with different subjects and discussing specific details of each observational experiment. Therefore, the aim of this paper is to combine the various datasets collected simultaneously in this margin within the frame of different projects and illustrate the effects of severe storms on the Gulf of Lions (GoL), transporting sediment particles and associated elements from the shelf down to the basin. Additionally, new data on particle composition at the basin site will be presented and discussed.

\section{Study area}

The GoL is a micro-tidal and river-dominated continental margin that is fed by the Rhone River and several minor rivers. The GoL continental shelf stores river sediment, which can be subsequently resuspended by storms with waves from the E-SE (E-SE storms) and exported to the slope by storm-induced downwelling and dense water cascading (Palanques et al., 2006; Ulses et al., 2008a). The GoL continental slope is incised by numerous submarine canyons. However, most of the near-bottom shelf-slope sediment transfer occurs through the southwesternmost submarine canyon (Cap de Creus Canyon), which is the final outlet before the constriction of the Cap de Creus promontory (Fig. 1). The main winds in the western part of the GoL are the northwesterly "Tramontane" and the southeasterly "Marin". On one hand, the cold and dry northerly "Tramontane" is responsible for the strong cooling and homogenization of the shelf water column in winter, which may promote dense shelf water formation. On the other, southeasterly storms are the main mechanism causing bottom sediment resuspension over the GoL shelf, since they can generate strong waves reaching exceptionally significant wave heights $\left(H_{\mathrm{s}}\right)>6 \mathrm{~m}$ and periods $\left(T_{\mathrm{p}}\right)<12 \mathrm{~s}$ (Ferré et al., 2005; Guillén et al., 2006).

\section{Methods}

The data presented in this paper comes from three different observational sites in the GoL from where near-bottom currents, water temperature and sediment fluxes were measured simultaneously. These observations have been

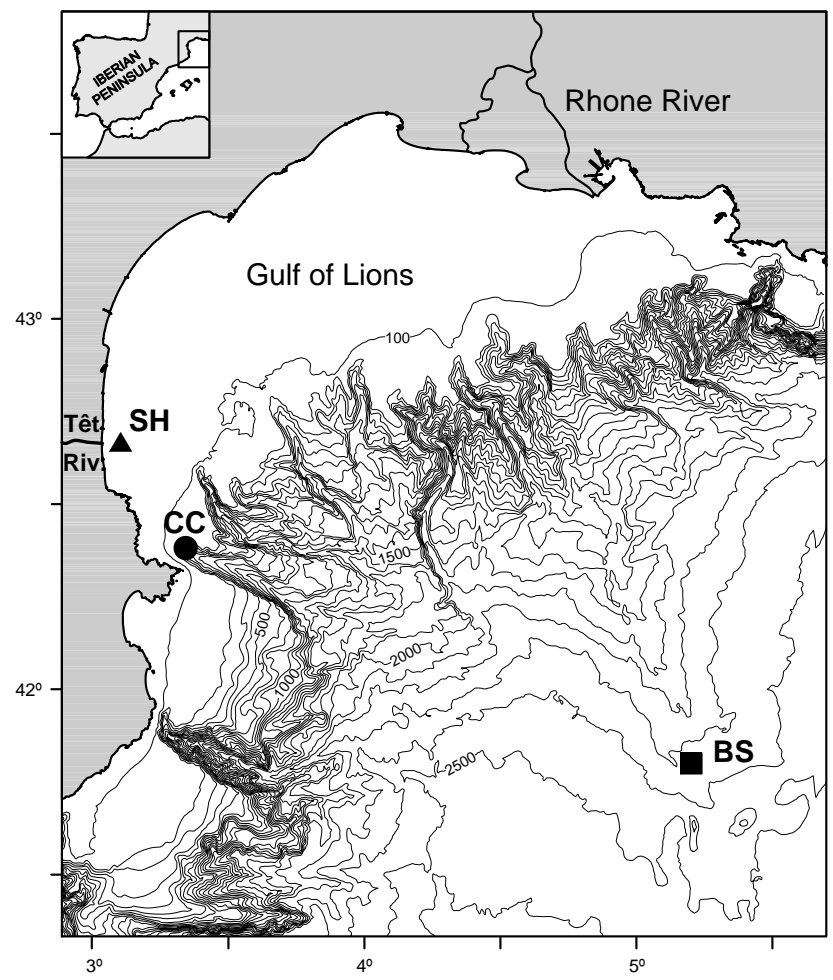

Fig. 1. Bathymetry map of the Gulf of Lions showing the location of the inner shelf ( $\mathrm{SH}$ ) instrumented tripod (triangle), the Cap de Creus (CC) canyon head mooring site (circle) and the basin site (BS) mooring (square).

combined with wave data from the GoL to assess the role of major storms in this region. Time series from the shelf were obtained from a tripod deployed $2 \mathrm{~km}$ off the mouth of the Têt River at a water depth of $28 \mathrm{~m}$; time series from the slope were collected by a mooring deployed at the head of the Cap de Creus submarine canyon at 300-m depth; and data from the basin were recorded by another mooring deployed at 2350-m depth (Fig. 1).

Continuous information on wave conditions in the western sector of the GoL was obtained by an autonomous RDI Sentinel $600 \mathrm{kHz}$ acoustic doppler current profiler (ADCP) equipped with a wave pressure sensor and deployed nearby the shelf tripod site. It was mounted on a bottom platform with an upward-looking configuration. Waves were measured during 20-min bursts at $2 \mathrm{~Hz}$ every $3 \mathrm{~h}$. Currents were measured between wave-burst measurements at $1 \mathrm{~Hz}$ and were averaged over that period. In this paper we show ADCP currents at $2 \mathrm{~m}$ above bottom (m.a.b.). The ADCP collected data between 26 November 2003 and 16 January 2004 and between 4 February and 26 March 2004. Additional wave data were obtained from a Datawell wave buoy deployed $11 \mathrm{~km}$ south of the study area. 
The shelf tripod was deployed twice, from 26 November 2003 to 12 December 2003 and from 4 February 2004 to 18 March 2004. It was equipped with an Aanderaa current meter (RCM 9) with pressure, temperature, conductivity and turbidity sensors, installed $1 \mathrm{~m}$ a.b. The sampling interval of the RCM 9 current meter was set to $5 \mathrm{~min}$. Three D\&A Instruments Optical Backscattering Sensors (OBS) were also mounted on the tripod. These instruments collected data every $3 \mathrm{~h}$ in 20 -min bursts logged at $2 \mathrm{~Hz}$. Laboratory calibrations were used to convert the signals from these instruments into Suspended Sediment Concentration (SSC). In this study, we present the burst-averaged SSC from the OBS mounted at $0.15 \mathrm{~m}$ a.b. In the first deployment, the tripod was knocked over during the peak of a strong storm on 4 December, after 8 days of sampling. However, the $0.15 \mathrm{~m}$ a.b. OBS continued to produce reliable data (see Guilén et al., 2006 for details).

Bottom shear stress $(\tau)$ was estimated using the combined wave-and-current boundary-layer model of Grant and Madsen (1986). The inputs to the model were wave-orbital velocity $\left(u_{\mathrm{rms}}\right)$, obtained by applying linear wave theory to the ADCP, $H_{\mathrm{s}}$ and $T_{\mathrm{p}}$ measurements, current speed $\left(u_{\mathrm{c}}\right)$ at $2 \mathrm{~m}$ a.b. and wave-current angle. The bottom was assumed to be flat and the bottom roughness was given by the sediment grain size (D50) (Guillén et al., 2006).

Concurrent with the shelf observations, an Aanderaa RCM11 current meter also equipped with pressure, temperature, conductivity and turbidity sensors was moored 5 m.a.b. in the Cap de Creus Canyon head from 1 November 2003 to 5 May 2004 with a mooring turn-around from 3 to 5 February The sampling interval of the canyon-head current meter was set to 20 min. Turbidity data recorded in FTU were converted into SSC following the methods described in Guillén et al. (2000).

The data at the basin site were obtained from a moored array deployed in the North Balearic Basin $\left(5^{\circ} 12^{\prime}\right.$; $41^{\circ} 48^{\prime}$ ) from November 2003 to April 2005. The array was equipped with an Aanderaa RCM 11 current meter with pressure and temperature sensors and a Technicap PPS $5 / 2$ conical sediment trap with a $1-\mathrm{m}^{2}$ collecting area and 24 receiving cups. The current meter was placed $220 \mathrm{~m}$ a.b. and the sediment trap $250 \mathrm{~m}$ a.b. The sediment trap collected 48 samples in the two consecutive deployments with a mooring turn-around in mid-September 2004. The trap-collecting intervals ranged from 5 to 15 days, depending on the season, and the current meter sampling interval was set at $60 \mathrm{~min}$. Sediment trap cups were filled with a borax-buffered $5 \%$ formaldehyde solution in $0.20-\mu \mathrm{m}$ filtered seawater before their deployment, to prevent sample degradation. Swimmers (those organisms deemed to have actively entered the trap) were removed from the samples by wet-sieving the sample through a 1mm nylon mess. Trapped material was split to divide the total sample into several homogeneous aliquots. To determine downward Total Mass Flux (TMF), sub-samples were filtered through pre-weighed cellulose acetate filters and dried overnight at $40^{\circ} \mathrm{C}$.

TMF was calculated from the sample dry weight, the collecting trap area and the sampling interval. Organic Carbon (OC) and total carbon contents were analyzed in 25\% $\mathrm{HCl}$ treated and non-treated samples, using an elemental analyzer (Thermo NA 2100 and EA Flash series 1112). Inorganic carbon was then calculated as the difference between total and OC. Organic matter content was estimated by multiplying the $\mathrm{OC}$ by 2 , the factor most commonly used in NW Mediterranean studies. Calcium carbonate content was calculated from inorganic carbon using the molecular mass ratio 8.33, assuming that all inorganic carbon was in the form of calcium carbonate. Biogenic silica (data not shown) was analyzed using a wet-alkaline extraction with sodium carbonate using the method described by Mortlock and Froelich (1989). Finally, the lithogenic fraction was obtained as the difference between the total mass and the rest of the main components (i.e. opal + organic matter + carbonates).

\section{Results}

During the 2003-2004 winter, there were two severe storms with waves coming from the E-SE sector during which maximum significant wave heights increased up to more than $7 \mathrm{~m}$ : one in early December 2003 and one in late February 2004 (Fig. 2). The early December event occurred while the shelf water was still stratified and was concurrent with a flood of all GoL rivers. The late February 2004 event took place when shelf water was unstratified and during the season of Dense Shelf Water Cascading (DSWC). More usual moderate storms with significant wave heights between 2.5 and $4 \mathrm{~m}$ occur mainly in autumn and winter and have a small impact in the off-shelf sediment transfer. As it has been stated before, for the purpose of this paper we will focus on these two extreme events, which recurrence interval is of the order of 50 years for the December event and of 10 years for the February event (Puertos del Estado).

\subsection{December major storm}

At the inner shelf site, the first major storm began at 17:30 $\mathrm{h}$ on 3 December. Six hours earlier, temperature decreased from 15.5 to $14.4^{\circ} \mathrm{C}$ ). The peak of the storm was at $02: 00 \mathrm{~h}$ on 4 December with an $H_{\mathrm{s}}$ of $8.45 \mathrm{~m}$ and turbidity reached $1.9 \mathrm{gl}^{-1}$ at 01:00 just before the tripod was knocked on its side. Near-bottom currents reached maximum values between 47 and $53 \mathrm{~cm} \mathrm{~s}^{-1}$ after the peak of the storm (Fig. 3). Bottom shear stresses reached $3.74 \mathrm{~N} \mathrm{~m}^{-2}$ (data not shown). The dominant current direction and sediment advection was towards the SSE.

At the canyon head sudden increases in temperature (from 13.4 to $15.5^{\circ} \mathrm{C}$ ) and current speed (from 2.5 to $>50 \mathrm{~cm} \mathrm{~s}^{-1}$ ) occurred at 01:35 h on 4 December, which generated the first 


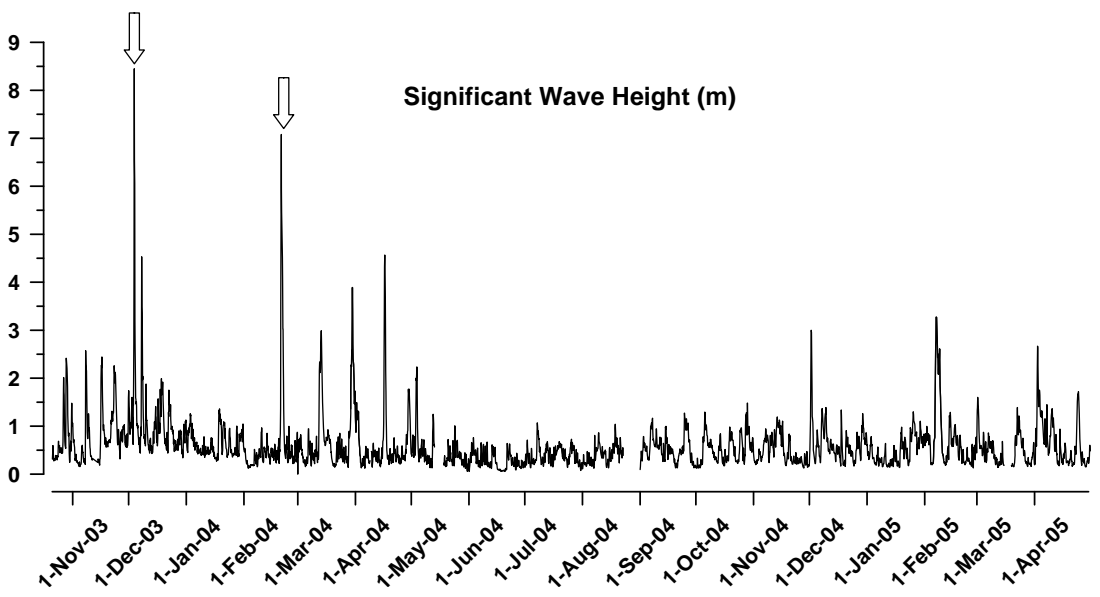

Fig. 2. Time series of significant wave height $\left(H_{\mathrm{S}}\right)$ at the inner shelf in front of the Têt River mouth (see location in Fig. 1) from October 2003 to April 2005. Storm events correspond to $H_{\mathrm{S}}$ peaks. Arrows point to the extreme E-SE storms with the highest $H_{\mathrm{S}}$ peaks occurring in early December and late February.

peaks of turbidity (from 0.8 to $19.2 \mathrm{mg} \mathrm{l}^{-1}$ ). At $04: 40 \mathrm{~h}$ SSC peaked suddenly up to $48 \mathrm{mg}^{-1}$ and shear stress to $0.54 \mathrm{~N} \mathrm{~m}^{-2}$ (data not shown). The event ended at 09:00 $\mathrm{h}$ with a sudden decrease in temperature, currents and turbidity that coincided with the decrease of the storm on the shelf (Fig. 3).

At the basin site, the temperature maintained values of around $13.13^{\circ} \mathrm{C}$ during and after the December 2003 major storm, (Fig. 3) and current speed ranged between 0.8 and $7.1 \mathrm{~cm} \mathrm{~s}^{-1}$. During and immediately after the storm, TMFs were low $\left(24 \mathrm{mg} \mathrm{m}^{-2} \mathrm{~d}^{-1}\right)$ and OC content and the OC/N ratio decreased to $3.99 \%$ and 7.12 , respectively, lithogenics also decreased to $35 \%$, whereas carbonate increased to $54.37 \%$. Opal maintained similar values (Fig. 4).

\subsection{February major storm}

At the inner shelf site, the second major storm began with a temperature decrease of $1^{\circ} \mathrm{C}$ at around $10: 40 \mathrm{~h}$ on 20 February. During the peak of the storm at around 03:00 h on 21 February, $H_{\mathrm{s}}$ reached $7 \mathrm{~m}$, generating shear stresses up to $2.61 \mathrm{~N} \mathrm{~m}^{-2}$ (data not shown) and turbidity values of $2.5 \mathrm{~g} \mathrm{l}^{-1}$ at $0.15 \mathrm{~m}$ a.b. Near-bottom currents maintained speeds higher than $20 \mathrm{~cm} \mathrm{~s}^{-1}$ (maximum speed: $42 \mathrm{~cm} \mathrm{~s}^{-1}$ ), advecting resuspended sediment towards the S-SE. After the peak of the storm, the waves decreased gradually but turbidity increased again, along with a decrease in temperature, giving a secondary peak one day later due to resuspended sediment advected from northern coastal areas (Fig. 3).

At the canyon head, the temperature decreased suddenly from 13.1 to $12.5^{\circ} \mathrm{C}$ at $16: 00$ on 20 February and current speed increased progressively up to $78 \mathrm{~cm} \mathrm{~s}^{-1}$ and shear stress up to $0.59 \mathrm{~N} \mathrm{~m}^{-2}$ (data not shown). Several turbidity peaks between 20 and $34 \mathrm{mg} \mathrm{l}^{-1}$ occurred between 02:00 and
16:00 h on 21 February and a major turbidity peak began at $22: 19 \mathrm{~h}$ maintaining values $>68 \mathrm{mg} \mathrm{l}^{-1}$ (over the sensor limit) for $10 \mathrm{~h}$. At the end of the storm, turbidity again exceeded $68 \mathrm{mgl}^{-1}$ at 17:00 $\mathrm{h}$ on 22 February, even with decreasing current speeds (Fig. 3).

At the basin site, temperature and current speed did not show any drastic change and maintained values around $13.13^{\circ} \mathrm{C}$ and between 1.4 and $5.7 \mathrm{~cm} \mathrm{~s}^{-1}$, respectively. However, the downward TMF of particles collected between 22 February and 3 March increased more than one order of magnitude from $50-60$ to $2823 \mathrm{mg} \mathrm{m}^{-2} \mathrm{~d}^{-1}$ (Fig. 3). The OC of the downward particulate matter decreased to $3.86 \%$ and the $\mathrm{OC} / \mathrm{N}$ ratio increased to 11.25 , whereas carbonate and opal decreased to $24.78 \%$ and $1.58 \%$, respectively, and lithogenic content increased to $65.90 \%$. OC flux increased by one order of magnitude, reaching $109.16 \mathrm{mg} \mathrm{m}^{-2} \mathrm{~d}^{-1}$ (Fig. 4).

\section{Discussion}

During the December and February severe storms, coastal water was exported off-shelf producing strong near-bottom currents (up to $82 \mathrm{~cm} \mathrm{~s}^{-1}$ ) on the canyon head due to storminduced downwelling, which was enhanced by DSWC in the February event. In addition to the sediment resuspension induced by the canyon currents, the highest waves during the peak of these storms, also resuspended sediment on the canyon head and the whole adjacent continental shelf (from the inner to the outer shelf) (Ulses et al., 2008a; Palanques et al., 2008). Although similar significant wave heights and canyon near-bottom currents were reached during both storms, their effects in transferring sediment offshore were different. The sediment flux increase at the canyon head was much greater (1-2 orders of magnitude) during the February 
INNER SHELF (SH)

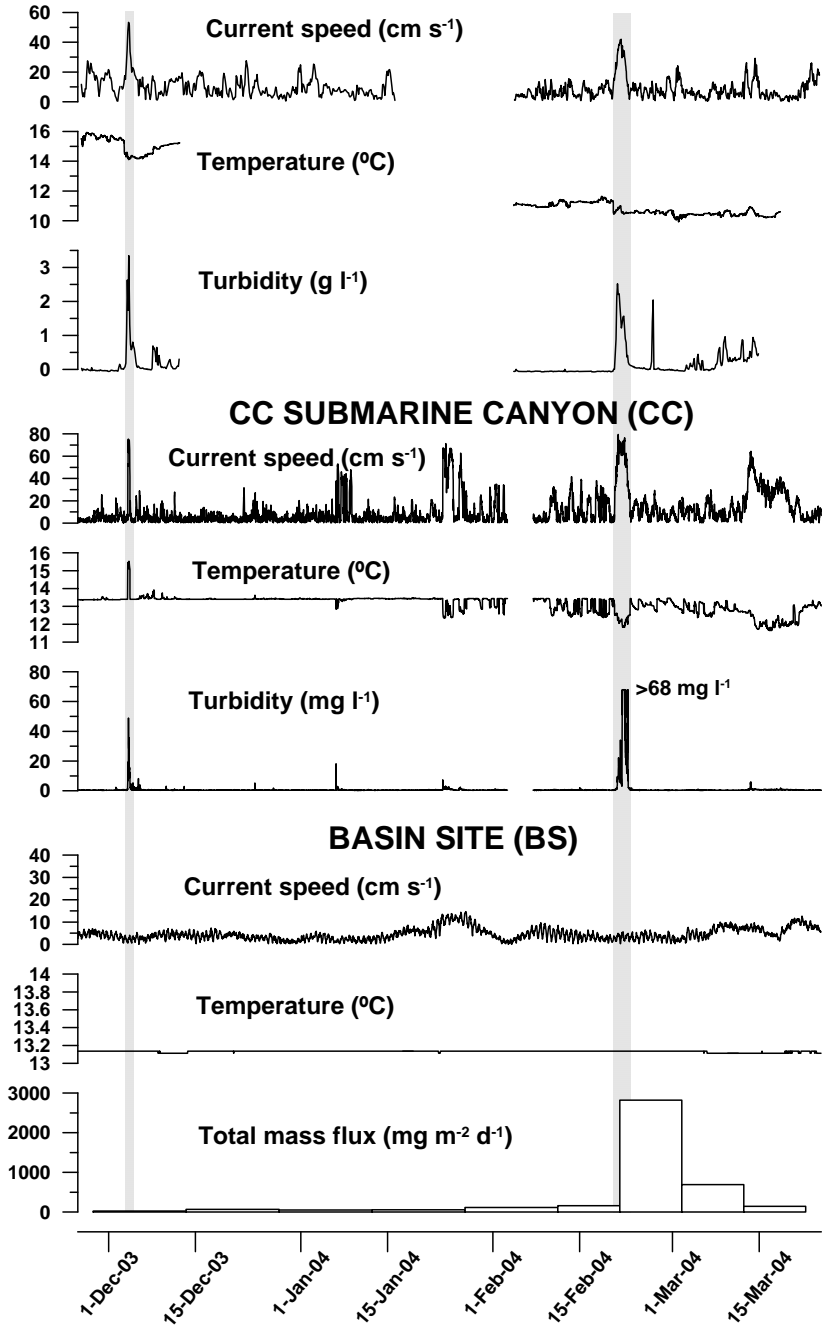

Fig. 3. Simultaneous time series of: near-bottom currents, nearbottom temperature and near-bottom turbidity from the inner shelf (SH) and the Cap de Creus (CC) submarine canyon; and nearbottom current speed, near-bottom temperature and downward total mass fluxes at the basin site (BS) during the deployment period. Grey bands represent the timing of major E-SE storms.

storm than during the December storm. At the basin site, particle fluxes also increased drastically (1-2 orders of magnitude) immediately after the February storm but not during the December storm (Palanques et al., 2009). One of the main differences between the two storms was that the February event occurred during the DSWC period, whereas the December event was at the end of the water stratification period, without cascading (Palanques et al., 2006; Ulses et al., 2008b). The downwelling induced by the December storm resuspended the canyon head sediment, but it ended quickly and suddenly due to restoration of shelf water stratification. This storm was too short $(9 \mathrm{~h})$ to allow the advection of sediment resuspended on the shallow shelf

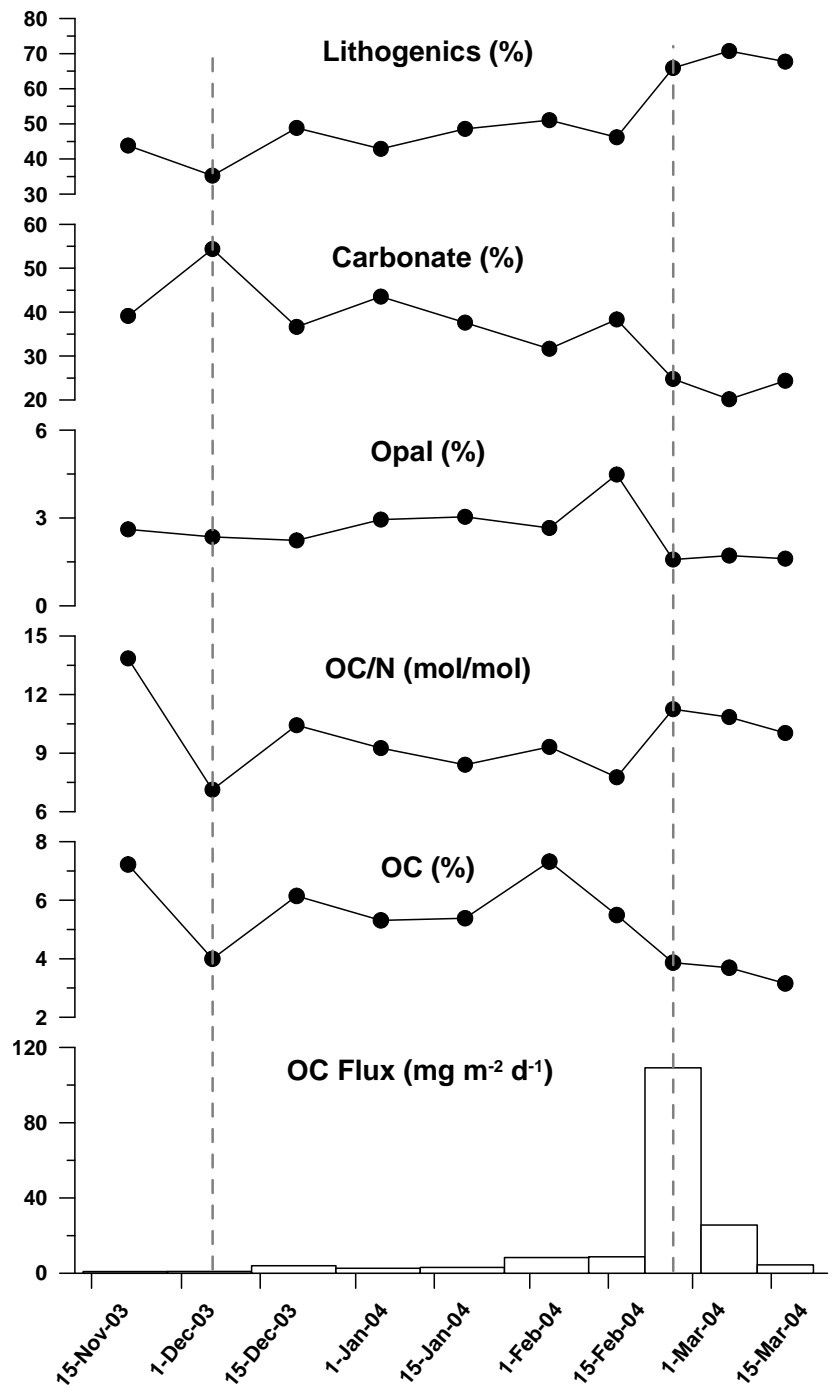

Fig. 4. Time series of lithogenics content, calcium carbonate content, Opal, OC/N ratio, organic carbon content and organic carbon flux at the basin site. Dashed lines represent the trap collecting intervals during which severe storms occurred.

to reach the canyon head (Palanques et al., 2006). In contrast, the downwelling induced by the February event, reinforced by DSWC, was long enough ( $43 \mathrm{~h}$ ) to transfer large amounts of resuspended sediment from shallow shelf areas to the canyon head and from there to the basin.

The February storm resuspended and flushed out most of the material previously deposited on the continental shelf, after a major flooding period (Guillén et al., 2006; Palanques et al., 2008). Modelling simulations showed that sediment in suspension within the dense water plume was transferred down to the density equilibrium level (about 700-m depth) and from there, it spread southwards along isobaths (Ulses et al., 2008a). The modelling of the plume did not indicate a basinward sediment flux increase because sediment transport 
continued beyond the equilibrium level at 700-m depth and became independent from the dense shelf water plume. However, increases in near-bottom currents and turbidity to more than $80 \mathrm{~cm} \mathrm{~s}^{-1}$ and $68 \mathrm{mgl}^{-1}$ at the canyon head suggest the formation of a low-density turbidity current able to maintain negative buoyancy and go deeper than the dense shelf water itself. The canyon slope was high enough to allow any possible decrease in the density difference due to entrainment of ambient water to be overridden by an increase in the density difference due to sediment erosion. In the deep canyon, the slope decreases and the low-density turbidity current probably decelerated. When its density became lower than the density of the ambient water body, the turbid plume could have initiated upward convection, generating detachments of Intermediate Nepheloid Layers (INLs), spreading over the deep basin where particles settled (Palanques et al., 2009).

Thus, in the western GoL, severe winter E-SE storms associated with cascading can cause significant sediment transport events that can reach the deep areas of the northwestern Mediterranean basin. This transport can also include contaminants, organic matter and other compounds associated with particulate matter. Sediment transport from the river to the slope is not usually direct but follows a complex, multi-step pattern controlled by a multi-event sequence (Guillén et al., 2006). The first repository areas for land-derived particles are in the GoL shallow prodeltas, exposing local ecosystems to both inorganic and organic contamination. Although many contaminants tend to be enriched in the prodelta areas, these areas do not constitute a permanent sink due to resuspension processes that affect especially those contaminants associated with organic matter, which may be more easily resuspended. In a seaward direction, however, anthropogenic influences diminish due to sediment dilution, particle sorting and biodegradation processes, with the exception of some contaminants that could be supplied from the atmosphere by man-made aerosols (Roussiez et al., 2006; Radakovitch et al., 2008).

Specific effects of storms in contaminated sediment dispersion are not well known. Average storms probably redistribute contaminated particles along and across the shelf, but major storms, such as the one occurring in February 2004, can resuspend and inject shallow sediment discharged from rivers towards the basin, flushing fresh and easily erodible sediment with its contaminant load through submarine canyons to the deep slope and basin. During these events, however, shelf-contaminated sediment is diluted by mixing with uncontaminated shelf-resuspended sediment and with canyon sediment resuspended along its downslope transport.

${ }^{14} \mathrm{C}$ and $\delta^{13} \mathrm{C}$ measured in the particulate matter collected during the February event in the Cap de Creus submarine canyon showed similar values to those of the shelf surface prodeltaic sediment (Tesi et al., 2010), indicating the dominant advection of shelf-resuspended sediment towards the canyon during this event. However, particulate matter reaching the basin site during the February event had a higher OC content $(3.8 \%)$ and a higher $\mathrm{C} / \mathrm{N}$ ratio (11.2) than at the submarine canyon but a similar opal content (OC: $1.3 \%$, OC/N 9.8, Opal: 1.6\%; Fabres et al., 2008). This suggests an additional input of recycled organic matter, (probably from the erosion of canyon and slope sediments that are depleted in opal), which would also fit with the increase in lithogenic content at the same basin site. Most of the DSWC pulses only reach the upper canyon region, leaving their sediment load where the current loses its transport capacity. From time to time, when a stronger event, such as that occurring in February, reaches deeper areas than usual, it can resuspend and again transport sediment deposited from previous DSWC events, mixing fresh shelf sediment with older slope sediment. During the few days that lasted the February 2004 event, the basin site received more sediment $\left(28.2 \mathrm{~g} \mathrm{~m}^{-2}\right)$ than during the rest of the year $\left(26.0 \mathrm{~g} \mathrm{~m}^{-2}\right)$ (Palanques et al., 2009). Therefore, these sudden pulses of sediment input from extreme storms change the more usual conditions in deep habitats. Besides the storms, intense DSWC pulses produced during dry, windy and cold years can also increase sediment fluxes in the basin. One of these years was 2005, when dense and turbid shelf water reached the basin site for 35 day. During that period of time, DSWC transported an amount of sediment one order of magnitude higher than during the February 2004 event. Thus, climatecontrolled processes like extreme storms and DSWC have a strong impact in both shallow and deep environments. In the case of DSWC, some deep impacts were defined for the organic carbon export (Canals et al., 2006) and for some deep-sea living communities (Company et al., 2008), but in the case of storms, the effects on deep Mediterranean environments are unknown. During extreme storm events occurring with cascading, the impact of the sediment flux increase on the deep ecosystems may alter the equilibrium of an environment that usually receives low distal terrestrial and atmospheric particle inputs along with primary-produced particles most of the time. This sediment flux can have the capacity to generate sediment gravity flows and increase the turbidity of deep Mediterranean waters.

Future perspectives of deep sediment transport with respect to the climate projections of extreme storms in the coming decades are a critical point. Modelling results for the Mediterranean Sea and the IPCC-A2 scenario for the twenty-first century predicts a warmer and drier climate over the entire basin (Somot et al., 2006) but the impact on the frequency and intensity of the GoL extreme storms is still not clear. Even the present frequency of these events is still not well known. The still relatively short timeseries of instrumental observations, the complex orography and bathymetry and the high wind field variability in the NW Mediterranean are some of the reasons why the longterm and probabilistic distributions of extreme wave storms 
is still achieved with great uncertainty (Sánchez-Arcilla et al., 2008). In this context, and with such limitations, the recurrence interval for an event as the February 2004 storm is of the order of tens of years (Puertos del Estado; SánchezArcilla, 2008). The same limitations apply in the estimation of the recurrence of extreme cascading events and from the available observations its recurrence interval is about 6-10 years (Canals et al. 2006).

\section{Conclusions}

In the GoL, the extreme E-SE storms during the cascading period can affect the whole continental margin down to the basin. They produce strong near-bottom currents at the Cap de Creus Canyon head and important increase of the downcanyon sediment fluxes, especially if they occur after a flooding period. Under these conditions, extreme storms resuspend and flush out most of the material recently deposited on the continental shelf through the Cap de Creus Submarine Canyon. This material can form lowdensity turbidity currents and be transferred beyond the dense shelf water plume to the basin where they feed near bottom nepheloid layers and increase deep sediment fluxes by several orders of magnitude. The transferred material, consisting mainly of resuspended sediment from the shelf and the canyon itself with its organic matter load, increases the organic carbon flux to the basin. Shelf-contaminated sediment can be also transferred but has the potential to be highly diluted by resuspended uncontaminated sediment. The final effects of the extreme storms in the deep GoL ecosystems are still unknown.

Acknowledgements. This study was supported by the European research projects EUROSTRATAFORM (EVK3-CT-2002-00079), and HERMIONE (ref. 544226354 ). We thank the officers and crew of the R/V Thetis II and the Nereis for their help and dedication during the cruises.

Edited by: J. Salat

Reviewed by: three anonymous referees

\section{References}

Canals, M., Puig, P., Durrieu de Madron, X., Heussner, S., Palanques, A., and Fabres., J.: Flushing submarine canyons, Nature, 444, 354-357, 2006.

Company, J. B., Puig, P., Sardà, F., Palanques, A., Latasa, M., and Scharek, R.: Climate influence on deep sea populations, PLoS ONE, 3(1), e1431, doi:10.1371/journal.pone.0001431, 2008.

Crockett, J. S. and Nittrouer, C. A.: The sandy inner shelf as a repository for muddy sediment: an example from northern California, Cont. Shelf Res., 24, 55-73, 2004.
De Stigter, H. C., Boer, W., Jesus Mendes, P. A., Jesus, C. C., Thomsen, L., van den Bergh, G. D., and Van Weering, T. C. E.: Recent sediment transport and deposition in Nazaré Canyon, Portuguese continental margin, Mar. Geol., 246(2-4), 144-164, 2007.

Fabres, J., Tesi, T., Velez, J., Batista, F., Lee, C., Calafat, A., Heussner, S., Palanques, A., and Miserocchi, S.: Seasonal and event-controlled export of organic matter from the shelf towards the Gulf of Lions continental slope, Cont. Shelf Res., 28(15), 1971-1983, 2008.

Fan, S., Swift, D. J. P., Traykovski, P., Bentley, S., Borgeld, J., Reed, C.W. and Niedoroda, A. W.: River flooding, storm resuspension, and event stratigraphy on the northern California shelf: observations compared with simulations, Mar. Geol., 210, 17-41, 2004.

Ferré, B., Guizien, K., Durrieu de Madron, X., Palanques, A., Guillén, J., and Grémare, A.: Fine-grained sediment dynamics during a strong storm event in the inner-shelf of the Gulf of Lion (NW Mediterranean), Cont. Shelf Res., 25, 2410-2427, 2005.

Geyer, W. R., Hill, P. S., Milligan, T. G., and Traykovski, P.: The structure of the Eel River plume during floods, Cont. Shelf Res., 20, 2067-2093, 2000.

Grant, W. D. and Madsen, O. S.: The continental shelf bottom boundary layer, Annu. Rev. Fluid Mech., 18, 265-305, 1986.

Guillén, J., Palanques, A., Puig, P., Durrieu de Madron, X., and Nyffeler, F.: Field calibration of optical sensors for measuring suspended sediment concentration in the Western Mediterranean, Sci. Mar., 64(4), 427-435, 2000.

Guillén, J., Bourrin, F., Palanques, A., Durrieu deMadron, X., Puig, P., and Buscail, R.: Sediment dynamics during "wet" and "dry" storm events on the Têt inner shelf (SW Gulf of Lions), Mar. Geol., 234, 129-142, 2006.

Mortlock, R. A. and Froelich, P. N.: A simple method for the rapid determination of biogenic opal in pelagic marine sediments, Deep-Sea Res., 36, 1415-1426, 1989.

Ogston, A. S., Cacchione, D. A., Sternberg, R. W., and Kineke, G. C.: Observations of storm and river flood-driven sediment transport on the northern California continental shelf, Cont. Shelf Res., 20, 2141-2162, 2000.

Oliveira, A., Santos, A. I., Rodrigues, A., and Vitorino, J.: Sedimentary particle distribution and dynamics on the Nazaré canyon system and adjacent shelf (Portugal), Mar. Geol., 246(24), 105-122, 2007.

Palanques, A., Puig, P., Guillén, J., Jiménez, J., Gracia, V., SánchezArcilla, A., and Madsen, O.: Near-bottom suspended sediment fluxes on the microtidal low-energy Ebro continental shelf (NW Mediterranean), Cont. Shelf Res., 22(2), 285-303, 2002.

Palanques, A., Durrieu de Madron, X., Puig, P., Fabres, J., Guillén, J., Calafat, A., Canals, M., and Bonnin, J.: Suspended sediment fluxes and transport processes in the Gulf of Lions submarine canyons. The role of storms and dense water cascading, Mar. Geol., 234, 43-61, 2006.

Palanques, A., Guillén, J., Puig, P., and Durrieu de Madron, X.: Storm-driven shelf-to-canyon suspended sediment transport at the southwestern end of the Gulf of Lions, Cont. Shelf Res., 28, 1947-1956, 2008.

Palanques, A., Puig, P., Latasa, M. and Scharek, R.: Deep sediment transport induced by storms and dense shelf water cascading in the northwestern Mediterranean basin, Deep-Sea Res. Pt. I, 56, 
425-434, 2009.

Puig, P., Ogston, A. S., Mullenbach, B. L., Nittrouer, C. A., and Sternberg, R. W.: Shelf-to-canyon sediment-transport processes on the Eel continental margin (northern California), Mar. Geol., 193, 129-149, 2003.

Radakovitch, O., Roussiez, V., Ollivier, P., Ludwig, W., Grenz, C., and Probst, J. L.: Input of particulate heavy metals from rivers and associated sedimentary deposits on the Gulf of Lion continental shelf, Estuar. Coast. Shelf S., 77, 285-295, 2008.

Roussiez, V., Ludwig, W., Probst, J. L., Monaco, A., Bouloubassi, I., Buscail, R., and Saragoni, G.: Sources and sinks of sedimentbound contaminant in the Gulf of Lions (NW Mediterranean Sea): a multi-tracer approach, Cont. Shelf Res., 26, 1843-1857, 2006.

Sánchez-Arcilla, A., González-Marco, D., and Bolaños, R. S: A review of wave climate and prediction along the Spanish Mediterranean coast, Nat. Hazards Earth Syst. Sci., 8, 1217 1228, doi:10.5194/nhess-8-1217-2008, 2008.

Somot, S., Sevault, F., and Déqué M.: Transient climate change scenario simulation of the Mediterranean Sea for the 21st century using a high-resolution ocean circulation model, Clim. Dynam., 27(7-8), 851-879, doi:10.1007/s00382-006-0167-z, 2006.
Tesi, T., Goñi, M. A., Langone, L., Puig, P., Canals, M., Nittrouer, C. A., Durrieu de Madron, X., Calafat, A., Palanques, A., Heussner, S., Davies, M. H., Drexler, T. M., Fabres, J., and Miserocchi, S.: Reexposure and advection of 14Cdepleted organic carbon from old deposits at the upper continental slope, Global Biogeochem. Cy., 24, GB4002, doi:10.1029/2009GB003745, 2010.

Traykovski, P., Geyer, W. R., Irish, J. D., and Lynch, J. F.: The role of wave-induced density-driven fluid mud flows for crossshelf transport on the Eel continental shelf, Cont. Shelf Res., 20, 2113-2140, 2000.

Ulses, C., Estournel, C., Durrieu de Madron, X., and Palanques, A.: Suspended sediment transport in the Gulf of Lion (NW Mediterranean): impact of extreme storms and floods, Cont. Shelf Res., 28, 2048-2070, 2008a.

Ulses, C., Estournel, C., Bonnin, J., Madron, X. D., and Marsaleix, P.: Impact of storms and dense water cascading on shelf-slope exchanges in the Gulf of Lion (NW Mediterranean), J. Geophys. Res.-Oceans, 113, C02010, doi:10.1029/2006JC003795, 2008b

Van Weering, T. C. E., De Stigter, H. C., Boer, W. ,and de Haas, H.: Recent sediment transport and accumulation on the NW Iberian margin, Prog. Oceanogr., 52, 349-371, 2002. 